\title{
NMDA Receptor Blockade and Spinal Cord Ischemia Due to Aortic Crossclamping in the Rat Model
}

\author{
F. Follis, K. Miller, O.U. Scremin, S. Pett, R. Kessler and J. Wernly
}

\begin{abstract}
Recent brain research proposes that, during ischemia, synaptically released excitatory amino acid neurotransmitters accumulate at toxic concentrations with ensuing neuronal death. Their action is mediated by the receptor subtype N-methyl-D-aspartate (NMDA). The protective effect of NMDA receptor blockade with intrathecal $\mathrm{MgSO}_{4}$ and $\mathrm{MK}-801$ was investigated during spinal cord ischemia induced by aortic occlusion of 12 minutes. Male Sprague-Dawley rats, 250-300g, underwent intrathecal administration of $20 \mu \mathrm{L}$ of normal saline ( $\mathrm{SA} n=16), \mathrm{MgO}_{4} \mathrm{lM}(\mathrm{MG} \mathrm{n}=16)$, or MK$801,25 \mathrm{mM}$ solutions (MK $\mathrm{n}=16$ ) in a randomized order. After 2 hours, the animals underwent occlusion of the thoracic aorta and subclavian arteries for $12 \mathrm{~min}$. An additional control group (CO $\mathrm{n}$ = 16) underwent occlusion for 12 minutes, without intrathecal injection. The animals were scored according to their functional performance (LS = lesion score) each day for four days by a blinded observer. Mean LS were calculated for each group at a given day. Treatment and control groups were not different at day $1(P=0.302)$. Group $M G$ was improved from groups $S A(P=<0.0039)$ and $C O$ $(\mathrm{P}=<0.0048)$ at day 4 . This study demonstrates that although intrathecal NMDA receptor blockade with $\mathrm{MgSO}_{4}$ or MK-801 does not prevent paraplegia due to spinal cord ischemia in the rat, it could however influence the rate of recovery after ischemic injury.
\end{abstract}

\begin{abstract}
Résumé: Blocage du récepteur NMDA et ischémie de la moelle épiniere due au clampage de l'aorte chez le rat. Selon des recherches résentes, certains neurotransmetteurs, les acides aminés excitateurs libérés par les synapses pendant l'ischémie, s'accumulent à des concentrations qui sont toxiques causant la mort neuronale. Leur action s'effectue par l'intermédiaire d'un sous-type de récepteur N-méthyl-D-aspartate (NMDA). Nous avons investigué l'effet protecteur d'un blocage du récepteur NMDA par injection de $\mathrm{MgSO}_{4}$ et de $\mathrm{MK}-80 \mathrm{l}$ pendant l'ischémie de la moelle épinière induite par une occlusion aortique de 12 minutes. Nous avons administré par voie intrathécale soit une solution de sérum physiologique $20 \mu \mathrm{L}(\mathrm{SA} n=16)$, de $\mathrm{MgSO}_{4} \mathrm{IM}(\mathrm{MG} n=16)$, ou de MK-801 , 25 mM (MK n = 16), à des rats mâles Sprague-Dawley de 250 à 300 gms. L'ordre d'administration des solutions était aléotoire. Après 2 heures, les animaux ont subi l'occlusion de l'aorte thoracique et des artères sousclavières pendant 12 minutes. Un groupe contrôle additionnel $(\mathrm{CO} n=16)$ a subi une occlusion de 12 minutes sans injection intrathécale. Un observateur agissant en aveugle a ensuite coté les animaux quotidiennement pendant quatre jours quant à leur performance fonctionelle $(\mathrm{CL}=$ cote de lésion). $\mathrm{La} \mathrm{CL}$ moyenne quotidienne a été calculée pour chaque groupe. Il n'y avait pas de différence entre les groupes traités et non traités au jour 1 ( $p=$ $0.302)$. Le groupe MG était amélioré par rapport aux groupes $S A(p=<0.0039)$ et $C O(p=<0.0048)$ au jour 4 . Cette étude démontre que, même si le blocage intrathécal du récepteur NMDA par le $\mathrm{MgSO}_{4}$ ou le $\mathrm{MK}-801$ ne prévient pas la paraplégie due à l'ischémie de la moelle épinière chez le rat, il peut influencer le taux de récupération après une lésion ischémique.
\end{abstract}

Can. J. Neurol. Sci. 1994; 21: 227-232

Extensive brain research over the past 25 years has identified glutamate and aspartate as the main excitatory amino acid neurotransmitters (EAA) in the mammalian central nervous system. Their action is mediated by 3 receptor subtypes: quisqualate, kainate and N-methyl-D-aspartate (NMDA). From studies on tissue culture, tissue slices and intact animals, ${ }^{1,2}$ it is believed that ischemic neuronal death is associated with EAA neurotransmitter release (excitotoxin theory). Under anoxic and/or ischemic conditions, a synaptically-released excitatory neurotransmitter accumulates at neurotoxic concentrations. Acting on the postsynaptic receptors, EAA produce influx of sodium, calcium and, secondarily, chloride. Neuronal swelling with cell

From the Department of Thoracic and Cardiothoracic Surgery (F.F., K.M., S.P., R.K., J.W.), University of New Mexico and West Los Angeles V.A. Medical Center and Department of Physiology (O.S.), University of California Los Angeles School of Medicine, Los Angeles.

RECEIVED AUGUST 3, 1993. ACCEPTED IN FNAL FORM MARCH I, 1994.

Reprint requests to: Fabrizio Follis, MD, University of New Mexico, Department of Thoracic and Cardiovascular Surgery, 2211 Lomas Blvd., Albuquerque, New Mexico, USA 87131 
lysis ensues. Neurons not killed by this rapid osmotic effect can be damaged more slowly by elevation of intracellular calcium leading to further receptor activation, ${ }^{3}$ proteolysis of neurofilaments, ${ }^{4}$ irreversible mitochondrial damage, ${ }^{5}$ breakdown of membrane phospholipids and release of arachidonate, ${ }^{6}$ with cell death.

There is growing evidence in the literature that the cascade of events leading to cell death can be aborted by EAA antagonists administered before the ischemic insult. Among them, NMDA antagonists are the most fully characterized and have been classified as competitive or non-competitive according to their site of action. The former prevent receptor activation by competing with the agonist for the transmitter recognition site. The latter act upon the ion channel with different mechanisms: $\mathrm{Mg}^{2+}$ for example, probably blocks the channel directly by precluding ionic conductance, while other compounds such as MK-801 ((+)-5-methyl-10, 11-dihydro-5H-dibeno (a, d) cyclohepten-5, 10-imine hydrogen maleate) bind to sites within the channel that are separate from those of divalent cations.

The purpose of this study was to investigate the protective effect of magnesium sulfate and MK-801, when administered intrathecally, during spinal cord ischemia induced by aortic cross-clamping in the rat model.

\section{Materials and Methods}

\section{Pilot studies}

Pilot studies were carried out to investigate the effects of intrathecal injection of $\mathrm{MgSO}_{4}$ and $\mathrm{MK}-801$ solutions.

Under halothane anesthesia 21 Sprague-Dawley male rats, $250-300 \mathrm{~g}$ body weight, underwent exposure of the interspace between $\mathrm{L} 4$ and $\mathrm{L} 5$ vertebrae and intrathecal injection of increasing doses of $1 \mathrm{M} \mathrm{MgSO}_{4}$ solution (5-30 $\mu \mathrm{L}$ ) with a 30 gauge needle. Five additional animals were subjected to injection of $20 \mu \mathrm{L}$ of normal saline.

In a parallel study, $20 \mu \mathrm{L}$ of a solution of increasing concentrations $(1,10,25,50 \mathrm{mM})$ of $\mathrm{MK}-801$ were injected intrathecally in 12 rats.

\section{Surgical preparation}

Male Sprague-Dawley rats $2-3$ months old and weighing $250-300 \mathrm{~g}$ were kept in polycarbonate cages with free access to food and water. Animal care was delivered according to the "Principles of Laboratory Animal Care" and the "Guide for the care and use of Laboratory Animals" (NIH Publication No. 85$23,1985)$. The animals were fasted overnight, then weighed and placed in a glass chamber with a continuous flow of $2.5 \%$ halothane until a deep level of anesthesia was reached. The rats were then removed and placed on a mask with continuous flow of halothane $1.4-1.6 \%$. With the animals in prone position, a 2 $\mathrm{cm}$ incision was made over the lumbar spine, the paraspinal muscles were lifted and the interspace between L4-L5 was exposed. Twenty $\mu \mathrm{L}$ of the appropriate solution according to the study group was injected in the subdural space with a 30 gauge needle connected to a syringe. The vertebrae were covered with the paraspinal muscles and the skin was closed with 3-0 silk. The animals were then allowed to recover for approximately $2 \mathrm{~h}$. At the end of this period they were anesthetized again and intubated with a 14 gauge intracath catheter $(7 \mathrm{~cm}$ long and $2.1 \mathrm{~mm}$ outer diameter) using a neonatal laryngoscope with a Miller 0 blade modified to a width of $7-8 \mathrm{~mm}$. The rats were ventilated with an open circuit volume respirator (Ugo Basile rodent ventilator, Stoelting Instrument Co., Varese, Italy) at $80 \mathrm{cycles} / \mathrm{min}$ with halothane $1.3 \%-1.5 \%$. Body temperature was monitored by a rectal probe and maintained at $37^{\circ} \mathrm{C} \pm 0.5^{\circ}$ with a thermal pad. A longitudinal incision was made through the skin in the sternal region. The chest wall was incised from the apex of the manubrium caudad along the left sternal border to the third rib. The thymus was excised and three catheters (PE-10) were placed around the aorta and the origins of the right and left subclavian arteries. The free ends were passed through a $4 \mathrm{~cm}$ tubing (PE 160) creating a snare. ${ }^{7.8}$ Under direct vision the snares were pulled close and secured with a clamp. The vascular occlusion was maintained for 12 minutes. Positive end expiratory pressure (10 $\mathrm{cm}$ of water) was instituted during the occlusion. The chest was closed and the snares were released and withdrawn at the end of the occlusion period. The rats were extubated as soon as they resumed spontaneous breathing. The animals were kept alive and observed for four days.

\section{Experimental protocol}

Sixty-four animals were divided in 4 groups of 16 (groups SA, MG, MK, CO). Groups SA, MG, MK were randomly selected to receive intrathecal administration of $20 \mu \mathrm{L}$ of normal saline, $\mathrm{MgSO}_{4} 1 \mathrm{M}$ or MK-801 $25 \mathrm{mM}$ solutions, respectively. The animals were allowed to recover for 2 hours. To assure the efficacy of the intrathecal injection, only the animals that developed transient paraplegia after administration of $\mathrm{MgSO}_{4}$ and those which showed the behavioral changes described in the results of pilot studies after injection of MK-801, were included in the next phase of vascular occlusion. The remainder were euthanized. This occurred $10 \%$ of the time due to the operator's random error of injecting the solution in the epidural instead of the intrathecal space. After the recovery period, they were subjected to 12 minutes vascular occlusion. Animals from group $\mathrm{CO}$ formed a control group and were subjected to $12 \mathrm{~min}$ occlusion, without intrathecal injection. All the rats were then recovered, scored at day 1, 2,3 and 4 and euthanized.

\section{Neurologic assessment instruments}

Neurological function was appraised according to the criteria established by LeMay et al. ${ }^{7,8}$ This lesion scoring system was devised to primarily evaluate lower motor function, and includes four indices of motor function and one of sensation (Table 1). Fifteen levels of deficits can be defined with a score of zero indicating normal animals and a score of fifteen indicating maximal impairment. Recently, we observed a highly statistically significant positive correlation between this lesion scoring system and spinal cord conduction time (calculated from the difference in latency between cortical somatosensory potentials evoked by stimulation of hindpaw and forepaw). These data confirmed the validity of the lesion scoring system as an objective test to evaluate neurological deficits. ${ }^{9}$ The lesion scoring system was administered by an operator unaware of the animal's experimental group.

\section{Statistics}

A population mean was calculated from individual weights, temperatures and intervals between injection and vascular 
occlusion for each experimental group. Differences between group means were tested by non parametric ANOVA (KruskalWallis). Multiple comparison of all pairs of samples was obtained with the Mann-Whitney 2 sample procedure. Analysis of scores was performed with unbalanced two-way ANOVA. In all statistical procedures an overall family error rate of 0.05 was achieved (Bonferroni adjustment for multiple comparisons). The Log-Rank test in SAS survival analysis procedure ${ }^{10}$ was used for testing whether the survival in the four groups was different.

\section{Results}

\section{Pilot studies}

Transient paraplegia lasting $5-6 \mathrm{hrs}$, followed by complete recovery, was produced in 5 rats by intrathecal injection of 20 $\mu \mathrm{L}$ of $1 \mathrm{M} \mathrm{MgSO}_{4}$. Among 16 animals, lower volumes resulted in an inconsistent rate of paraplegia and higher volumes in respiratory paralysis. Five additional animals underwent subdural administration of $20 \mu \mathrm{L}$ of normal saline and were not paraplegic (control group). Thus transient paraplegia after subdural administration of $\mathrm{MgSO}_{4}$ was chosen as an end point of regional effect on the spinal cord.

The animals that received intrathecal injection of MK-801 did not become paraplegic but displayed severe behavioral changes. At the lowest concentration $(1 \mathrm{mM})(\mathrm{n}=2)$ no effect was seen. A $10 \mathrm{mM}(\mathrm{n}=3)$ concentration produced locomotor hyperactivity, and catalepsy/somnolence was associated with the $25(\mathrm{n}=1)$ and $50 \mathrm{mM}(\mathrm{n}=2)$ concentrations. Twenty $\mu \mathrm{L}$ of the $25 \mathrm{mM}$ MK-801 solution injected in the subdural space of 4 rats resulted in a state of somnolence and catalepsy which lasted on average 1 hour, followed by a period of increased locomotor activity with ataxia, which resolved completely 4 hours later. These behavioral effects have been observed by others ${ }^{11,12}$ after intraperitoneal injection and provided an end point for regional effect.



Figure 1: 12.0 min occlusion: Group mean lesion scores for each day. Numbers shown are the number of observations for each day in each experimental group.
Table 1: Lesion scoring system for neurological function. (After LeMay et al.)

\section{Deficit score}

Walking with lower extremities (LE):

$0 \quad$ No evidence of deficit

1 Toes flat under body when walking but ataxia exists

$2 \quad$ Knuckle walks

3 Movements in LE but no knuckle walk

4 No movements, drags LE

\section{Horizontal rope platform: $\left(^{*}\right.$}

$0 \quad$ Grasps rope and pulls up with LE

$1 \quad$ Raises LE and grasps rope without pulling

2 Raises LE but cannot grasp rope

3 Does not raise LE

\begin{tabular}{ll}
\hline & Rotating screen: (\#) \\
0 & LE grasp screen to 180 degree $>5 \mathrm{sec}$ \\
1 & LE grasp screen to 180 degree $<5 \mathrm{sec}$ \\
2 & LE grasp screen past vertical but not to 180 degree \\
3 & LE fall from screen past vertical $(270-180$ degree $)$ \\
\hline & $\quad$ Wooden bar 1 in. in diameter at $\mathbf{4 5}$ degree: (@) \\
0 & LE grasp bar $>10 \mathrm{sec}$ \\
1 & LE grasp bar $>5$ sec \\
2 & LE grasp bar $<5$ sec \\
3 & LE slide off bar without grasping
\end{tabular}

3 LE slide off bar without grasping

\section{Pain sensation:}

$0 \quad$ Withdrawal to toe pinch

1 Reacts or squeals to toe pinch but does not withdraw

2 No reaction to toe pinch

(*) Horizontal rope platform measures $15 \mathrm{~cm} \times 15 \mathrm{~cm}$ with $1 / 4$ inch nylon rope; the upper extremities are placed on platform edge and a normal rat pulls LE up onto platform.

(\#) A square wire screen, $30 \mathrm{~cm} \times 30 \mathrm{~cm}$ in size, with $1 / 4$ inch holes; the rat is placed on horizontal screen, $(0$ degree $)$ then the screen is rotated down through the vertical position (270 degrees) to the inverted position (180 degrees). A normal rat grasps the screen with LE for $>5 \mathrm{sec}$ when rotated to 180 degrees.

(@) Wooden bar is $50 \mathrm{~cm}$ long and $2.5 \mathrm{~cm}$ wide; a normal rat grasps the wooden bar with LE for more than 10 seconds.

Printed with permission from "Paraplegia in the rat induced by aortic cross-clamping: Model characterization and glucose exacerbation of neurologic deficit", Daniel R. LeMay et al., first published in the Journal of Vascular Surgery, 1987, volume 6, issue 4, page 384.

\section{Group match and lesion score}

The difference between scores at day 1 was not significant $(P=0.302)$. At day 4 the $L S$ of group $M G$ was improved from groups $\mathrm{SA}(\mathrm{P}=<0.0039)$ and $\mathrm{CO}(\mathrm{P}=<0.0048)$. The $\mathrm{MK}$ group was not better than SA $(P=0.044$ : with Bonferroni adjustment a $P<0.0083$ was considered significant) (Figure 1).

Differences between groups were noted when the mean weights (groups $\mathrm{SA}$ and $\mathrm{CO}, \mathrm{P}=0.003 ; \mathrm{MG}$ and $\mathrm{MK}, \mathrm{P}=0.01$; $\mathrm{MK}$ and $\mathrm{CO}, \mathrm{P}=0.0001$ ), intervals between injections and vascular occlusion (groups MG and $\mathrm{MK}, \mathrm{P}=0.01$ ) and temperatures (groups $\mathrm{SA}$ and $\mathrm{CO}, \mathrm{P}=0.005 ; \mathrm{MK}$ and $\mathrm{CO}, \mathrm{P}=0.0007$ ) 
were analyzed. The differences in weights, intervals and temperatures were less than $47 \mathrm{~g}, 36 \mathrm{~min}$, and $0.6^{\circ} \mathrm{C}$, respectively. Survival analysis showed differences among the four groups ( $P$ $=0.032$ ), and post-hoc multiple comparison revealed that $\mathrm{CO}$ survival was significantly different from $M G(P=0.035)$ and SA $(P=0.024)$. However, treatment groups $(M K, M G)$ and saline group ( $\mathrm{SA})$ were not different $(\mathrm{P}=0.37)$.

\section{Discussion}

This rat model provides a highly reproducible model of paraplegia $^{8}$ with an extensive behavioral repertoire that allows sophisticated neurologic assessment and detection of subtle degrees of neurologic impairment. The lesion score used in the present investigation has been validated by histologic and electrophysiologic studies in a previous publication. ${ }^{9}$ Commonly, both the white and gray matter of the lower thoracic and lumbar cord are involved to varying degrees by the ischemic injury.

Blockade of the NMDA receptors of the lumbar and lower thoracic cord with $\mathrm{MgSO}_{4}$ or MK-801 did not prevent postoperative paraplegia of rats subjected to spinal cord ischemic injury by occlusion of both subclavian arteries and the descending thoracic aorta for 12 minutes. However, intrathecal administration of $\mathrm{MgSO}_{4}$ did improve the ultimate recovery from spinal cord ischemic injury. This was an interesting but unexpected finding, and, had it been known during the design of the experiment, long term outcome would have been desirable. Although some differences among groups were found in the mean weights, temperatures, and intervals between intrathecal injection and vascular occlusion these were not present between treatment groups (MG, MK) and saline group (SA) and therefore cannot be accounted responsible for influencing the data. Although survival was not an end point of this study, the difference between the groups which received intrathecal injection (SA, MG, MK) and the control group (CO) is intriguing and might relate to the protective effect of cerebrospinal fluid drainage, with consequent decrease in tissue pressure and improvement of perfusion as proposed by some authors. ${ }^{13}$ For the purposes of this study, the real control group was the saline (SA) and there was no difference between this group and the treatment groups.

Criticism can be construed over the choice for intrathecal rather than intravenous administration of NMDA antagonist. In this respect, recent experimental and clinical research ${ }^{13-15}$ has explored the use of intrathecal compounds like papaverine or tetracaine. Accordingly, the systemic effects of intravenous administration are avoided and maximal concentration of the drug in the section of spinal cord to be protected is achieved. In the animal model, intravenous injection of $\mathrm{MgSO}_{4}$ produces hypotension ${ }^{16-18}$ and MK-801 causes hypertension and tachycardia. ${ }^{19}$ These effects would be poorly tolerated in patients undergoing repair of thoracoabdominal aneurysms who often have atherosclerotic heart disease. Thus, we chose intrathecal administration with local diffusion to the lower thoracic and lumbar cord, the segments commonly involved by ischemic injury following occlusion of the thoracic aorta. Previous work with chronic catheterization of the spinal subarachnoid space in the rat had established that a $20 \mu \mathrm{L}$ volume extended as far as $3-4$ $\mathrm{cm}$ from the injection site. ${ }^{20}$ In a way this was very similar to the focal microinfusion into the rat hippocampus of the
NMDA receptor antagonist APH (D-2-amino-7-phosphonoheptanoate) described by Simon et al. ${ }^{21}$

It can also be argued that the lack of a protective effect was the result of insufficient amounts of the compounds reaching the spinal cord. In order to address this problem, we eliminated all the animals which did not show paraplegia after $\mathrm{MgSO}_{4}$ injection and the described behavioural effects after MK-801 administration. Our $20 \mu \mathrm{L}$ of a $25 \mathrm{mM}$ MK-801 solution translates to a dose of $0.6 \mathrm{mg} / \mathrm{kg}$ for a $300 \mathrm{~g}$ rat, but since the drug is diffused in a small space, it is likely that the true concentration is underestimated. Even assuming a concentration four fold higher, it still falls in the range $(0.3 \mathrm{to} 3 \mathrm{mg} / \mathrm{kg}$ ) for which neuroprotection has been demonstrated in the gerbil model, when injected intraperitoneally. ${ }^{11,12}$

Another point of contention could be that the majority of previous experiments have been carried out on the hippocampal pyramidal cells notoriously rich in NMDA receptors, and questions can be raised about the importance of NMDA receptors in the spinal cord, and the basis for a possible protective effect following their blockade during ischemia. Although not as extensively as in the brain, several studies have identified a possible role for NMDA receptors in the monosynaptic and polysynaptic pathways of spinal cord motoneurons, interneurons and dorsal horn cells of rat and cat models..$^{22-24}$

Earlier reports in the literature have repeatedly underscored the protective effect of NMDA receptor blockade during cerebral and spinal cord ischemia. NMDA-associated neuronal loss was attenuated in dissociated cell cultures prepared from mouse neocortex by phencyclidine (PCP) and MK-801.25 Irreversible anoxic neuronal injury was prevented in rat hippocampal slices by NMDA blockade with $\mathrm{Mg}^{2+} \cdot{ }^{26}$ Furthermore, MK-801 injected intraperitoneally, protected gerbil hippocampal pyramidal neurons from ischemia. The effect was present if the compound was administered before the ischemic insult ${ }^{11}$ and following ischemia to prevent the delayed neuronal death. ${ }^{12}$ Other NMDA receptor antagonists have also been shown to have a protective effect in the gerbil ischemia model. ${ }^{27}$

The work done to date on spinal cord protection during ischemia from NMDA receptor blockade is less extensive. Four studies have been reported in the rabbit model. Kochhar et al. ${ }^{19}$ have observed a shift to the right of the paraplegia doseresponse curve after intravenous administration of MK-801 (1 $\mathrm{mg} / \mathrm{kg}$ ), with a $75 \%$ increase in the duration of ischemia to produce paraplegia. The weakness of the study however lies in the evaluation of the neurological deficits: because of the characteristic ambulatory behavior of rabbits (hopping gait) the motor repertoire of hindlimbs is limited and unsuitable for a fine evaluation of neurologic deficits.

Conversely, Yum et al.$^{28}$ employed a quantitative analysis of the spinal cord injury with neuronal count. Administration of MK-801 (1 mg/kg) $5 \mathrm{~min}$ after reperfusion resulted in a significantly higher number of surviving motoneurons than in the control group. Unfortunately, the histologic studies were performed 48 hours after reperfusion, at a time when spinal cord histology is notoriously unreliable. The remaining two studies ${ }^{16,17}$ investigate the protective effect of $\mathrm{Mg}^{2+}$. The data reported by Vacanti ${ }^{16}$ are clouded by the use of $\mathrm{Mg}^{2+}$ in combination with hypothermia, a modality well known to reduce the extent of 
spinal cord injury. In Robertson's study ${ }^{17}$ the neurologic outcome was not significantly different from the control group.

As an additional comment, the rabbit model is known for its peculiar spinal cord blood supply originating from the abdominal aorta, an anatomical finding different from any other species, human included. In contrast, close affinity exists between the rat and human spinal cord blood supply.

In sharp contrast with the above mentioned studies, however, the most recent literature reveals few studies showing no protection from NMDA receptor blockade in models of cerebral ischemia in cats and dogs. ${ }^{29.30}$

Fleisher et al. ${ }^{29}$ attempted to reconcile contrasting results in the literature over the protective effect of NMDA receptor blockade during ischemic injury, by underscoring the differences in pathophysiology of incomplete focal ischemia versus complete global ischemia. The former is characterized by an area of ischemia surrounded by zones where blood flow is diminished but still present; under these circumstances it appears that NMDA blockade can provide neuronal protection. The latter consists of severe ischemia with absent blood flow: NMDA blockade is not beneficial.

This attractive interpretation, however, was mitigated by another recent study which showed no protective effect of MK801 during partial global ischemia in the newborn piglet. ${ }^{31}$

If we try to reconcile the data reported in the literature, ours included, we can postulate that protection of NMDA receptor blockade during ischemia may vary according to the animal model, the experimental conditions and the antagonist studied. Alternatively, the beneficial effect may be present at different times after ischemia, as in our model where NMDA blockade did not prevent paraplegia but significantly influenced the rate of recovery.

The concept of evaluating the protective effects of a therapeutic intervention by measuring the rate of recovery from an ischemic injury, in addition to assessing the immediate neurologic outcome, has not been previously stressed. Among the studies mentioned above, end points were evaluated between 2 and $48 \mathrm{hr}$ in six ${ }^{14,16,17,19,21,28}$ between 72 and $96 \mathrm{hr}$ in three $\mathrm{e}^{27,30,31}$ and as late as 7 days in only one..$^{29} \mathrm{We}$, too, were focusing on the immediate effect of NMDA blockade, and the improvement in the speed of recovery was an unexpected finding. Without doubt a longer period of observation, 4 weeks for example, would have provided more definitive data, and perhaps showed a beneficial effect also for the MK group.

In summary, the following conclusions can be drawn: 1) NMDA blockade with intrathecal injection of $\mathrm{MgSO}_{4}$ or $\mathrm{MK}$ 801 does not prevent paraplegia produced by 12 minutes of aortic clamping in the rat model. 2) NMDA blockade with intrathecal injection of $\mathrm{MgSO}_{4}$ significantly improved the rate of recovery of the neurologic deficit. 3) After an initial enthusiasm in the literature over the beneficial effects of NMDA blockade, more studies are now being published showing no effect making the excitotoxic theory controversial. 4) Long term outcome and rate of recovery, in addition to short term neurologic evaluation, should be an end point for testing experimental compounds in the animal model.

\section{ACKNOWLEDGEMENTS}

We would like to thank Edward J Bedrick, PhD and Clifford Qualls, PhD (NIH Grant MO1 RR00997) for assistance in the statistical evaluation of data and Deborah L Heuser for assistance in preparation of this manuscript. This work was supported by a Grant-In-Aid from the American Heart Association with funds contributed in part by the New Mexico Affiliate, and by BRSG S07 RR-05583-25 awarded by the Biomedical Research Support Grant Program, Division of Research Resources, National Institutes of Health.

\section{REFERENCES}

1. Rothman SM, Olney JW. Excitotoxicity and the NMDA receptor. Trends Neurosci 1987; 10(7): 299-302.

2. Rothman SM, Olney JW. Glutamate and the pathophysiology of hypoxic-ischemic brain damage. Ann Neurol 1986; 19(2): 105111.

3. Baudry M, Bundman MC, Smith EK, Lynch GS. Micromolar calcium stimulates proteolysis and glutamate binding in rat brain synaptic membranes. Science 1981; 212: 937-938.

4. Gilbert DS, Newby BJ, Anderton BH. Neurofilament disguise, destruction and discipline. Nature 1975; 256: 586-589.

5. Farber JL, Chien KR, Mittnacht S. Myocardial ischemia: the pathogenesis of irreversible cell injury in ischemia. Am J Pathol 1981; 102(2): 271-281.

6. Wolfe LS. Eicosanoids: prostaglandins, thromboxanes, leukotrienes and other derivatives of carbon-20 unsaturated fatty acids. J Neurochem 1982; 38(1): 1-14.

7. LeMay DR, Neal S, Zelenock GB, D'Alecy LG. Paraplegia in the rat induced by aortic cross-clamping: model characterization and glucose exacerbation of neurologic deficit. J Vasc Surg 1987; 6(4): 383-390.

8. LeMay DR, Lu AC, Zelenock GB, D'Alecy LG. Insulin administration protects from paraplegia in the rat aortic occlusion model. $J$ Surg Res 1988; 44: 352-358.

9. Follis F, Scremin OU, Blisard KS, et al. Selective vulnerability of white matter during spinal cord ischemia. J Cereb Blood Flow Metab 1993; 13(1): 170-178.

10. SAS Institute Inc. SAS/STAT User's Guide, Version 6, Fourth Edition, Volume 2. Cary, NC:SAS Institute Inc., 1989.

11. Gill R, Foster AC, Woodruff GN. Systemic administration of MK801 protects against ischemia-induced hippocampal neurodegeneration in the gerbil. J Neurosci 1987; 7(10): 3343-3349.

12. Gill R, Foster AC, Woodruff GN. MK-801 is neuroprotective in gerbils when administered during the post-ischaemic period. Neuroscience 1988; 25(3): 847-855.

13. Svensson LG, Grum DF, Bednarski M. Appraisal of cerebrospinal fluid alterations during aortic surgery with intrathecal papaverine administration and cerebrospinal fluid drainage. J Vasc Surg 1990; 11: 423-429.

14. Breckwoldt WL, Genco CM, Connolly RJ, Cleveland RJ, Diehl JT. Spinal cord protection during aortic occlusion: efficacy of intrathecal tetracaine. Ann Thorac Surg 1991; 51: 959-963.

15. Svensson LG, von Ritter CM, Groeneveld HT. Cross-clamping of the thoracic aorta: influence of aortic shunts, laminectomy, papaverine, calcium channel blocker, allopurinol and superoxide dismutase on spinal cord blood flow and paraplegia in baboons. Ann Surg 1986; 204: 38-47.

16. Vacanti FX, Ames A, III. Mild hypothermia and $\mathrm{Mg}^{2+}$ protect against irreversible damage during CNS ischemia. Stroke 1984; 15(4): 695-698.

17. Robertson CS, Foltz R, Grossman RG, Goodman JC. Protection against experimental ischemic spinal cord injury. J Neurosurg 1986; 64(4): 633-642.

18. Altura BM, Altura BT. Magnesium ions and contraction of vascular smooth muscles: relationship to some vascular diseases. Fed Proc 1981; 40(12): 2672-2679.

19. Kochhar A, Zivin JA, Lyden PD, Mazzarella V. Glutamate antagonist therapy reduces neurologic deficits produced by focal central nervous system ischemia. Arch Neurol 1988; 45: 148-153. 
20. Yaksh TL, Rudy TA. Chronic catheterization of the spinal subarachnoid space. Physiol Behav 1976; 17(6): 1031-1036.

21. Simon RP, Swan JH, Griffiths T, Meldrum BS. Blockade of $\mathrm{N}$-methyl-D-aspartate receptors may protect against ischemic damage in the brain. Science 1984; 226: 850-852.

22. Evans RH, Watkins JC. Specific antagonism of excitant amino acids in the isolated spinal cord of the neonatal rat. Eur $\mathrm{J}$ Pharmacol 1978; 50(2): 123-129.

23. Davies J, Watkins JC. Selective antagonism of amino acid-induced and synaptic excitation in the cat spinal cord. J Physiol 1979; 297: 621-635.

24. Lodge D, Headley PM, Curtis DR. Selective antagonism by D-a-aminoadipate of amino acid and synaptic excitation of cat spinal neurons. Brain Res 1978; 152(3): 603-608.

25. Goldberg MP, Viseskul V, Choi DW. Phencyclidine receptor ligands attenuate cortical neuronal injury after $\mathrm{N}$-methyl-D-aspartate exposure or hypoxia. J Pharmacol Exp Ther 1988; 245(3): 10811087.

26. Clark GD, Rothman SM. Blockade of excitatory amino acid receptors protects anoxic hippocampal slices. Neuroscience 1987; 21(3): $665-671$.
27. Boast CA, Gerhardt SC, Pastor G, et al. The N-methyl-D-aspartate antagonists CGS 19755 and CPP reduce ischemic brain damage in gerbils. Brain Res 1988; 442(2): 345-348.

28. Yum SW, Faden AI. Comparison of the neuroprotective effects of the N-methyl-D-aspartate antagonist MK-801 and the opiatereceptor antagonist nalmefene in experimental spinal cord ischemia. Arch Neurol 1990; 47(3): 277-281.

29. Fleischer JE, Tateishi A, Drummond JC, et al. MK-801, an excitatory amino acid antagonist, does not improve neurologic outcome following cardiac arrest in cats. J Cereb Blood Flow Metab 1989; 9(6): 795-804.

30. Sterz F, Leonoy Y, Safar P, et al. Effect of excitatory amino acid receptor blocker, MK-801, on overall neurologic and morphologic outcome after prolonged cardiac arrest in dogs. Anesthesiology 1989; 71(6): 907-918.

31. LeBlanc MH, Vig V, Smith B, et al. MK-801 does not protect against hypoxic-ischemic brain injury in piglets. Stroke 1991; 22(10): 1270-1275. 